\title{
A new species of Berkleasmium from Ulyanovsk, Russia
}

\author{
Hüseyin $\mathrm{E}^{1}$, Selçuk $\mathrm{F}^{1}$ and Churakov $\mathrm{BP}^{2}$ \\ ${ }^{1}$ Ahi Evran University, Arts and Sciences Faculty, Department of Biology, Kirşehir, Turkey \\ ${ }^{2}$ Ulyanovsk State University, Ecology Faculty, Ulyanovsk, Russia
}

Hüseyin E, Selçuk F, Churakov BP 2014 - A new species of Berkleasmium from Ulyanovsk, Russia. Mycosphere 5(3), 462-466, Doi 10.5943/mycosphere/5/3/8

\begin{abstract}
A fungus belonging to the sporodochial, dematiaceous, dictyosporous hyphomycete genus Berkleasmium was found on bark of dead twigs of Rhamnus catharticus in Ulyanovsk Province of Russia. It is described as a new species, Berkleasmium dudkae, illustrated and compared with allied species.
\end{abstract}

Key words - anamorphic fungi - Ascomycota - hyphomycetes - new taxon

\section{Introduction}

In 2013, mycologists of the Ahi Evran University (Turkey) collected numerous samples of micromycetous fungi on forest trees and shrubs in some areas of Ulyanovsk Province of Russia. Examinations of the samples have been carried out within the frame of a Research Program of the Ulyanovsk State University (Russia) and Ahi Evran University (Turkey). Several anamorphic fungi have been found on substrates of these collections. A sporodochial, dematiaceous, dictyosporous hyphomycete belonging to the genus Berkleasmium Zobel was found in the samples and proved to be a new species.

\section{Materials \& Methods}

The samples for the present study were collected in 2013 during field trips to the forests of the Ulyanovsk region (Russia). Thereafter the samples were taken to the laboratory and examined morphologically and photographed using an Olympus SZX 16 - (Japan) a compound binocular stereomicroscope. The collections were examined in distilled water and for microphotographs Leica DM 3000 (Axio imager 2 equipped with Nomarski differential interference contrast optics) microscope was used. The identification of the new species was accomplished through comparison with descriptions of other species hitherto assigned to Berkleasmium. Type material is deposited at the Ahi Evran University, Arts and Sciences Faculty, Department of Biology, Kırşehir Province, Turkey.

\section{Results}

The following description is based on fungal material recently found in Russia on bark of a dead twig of Rhamnus catharticus L. brush which proved to be a new species. 
Berkleasmium dudkae E. Huseyin \& F. Selçuk, sp. nov.

Figs 1-49

MycoBank MB808452

Etymology - dudkae derived to honour the Ukrainian mycologist Prof. Dr. Irina Alexandrovna Dudka, on the occasion of her $80^{\text {th }}$ birthday in 2014 , recognising her outstanding contributions to mycology.

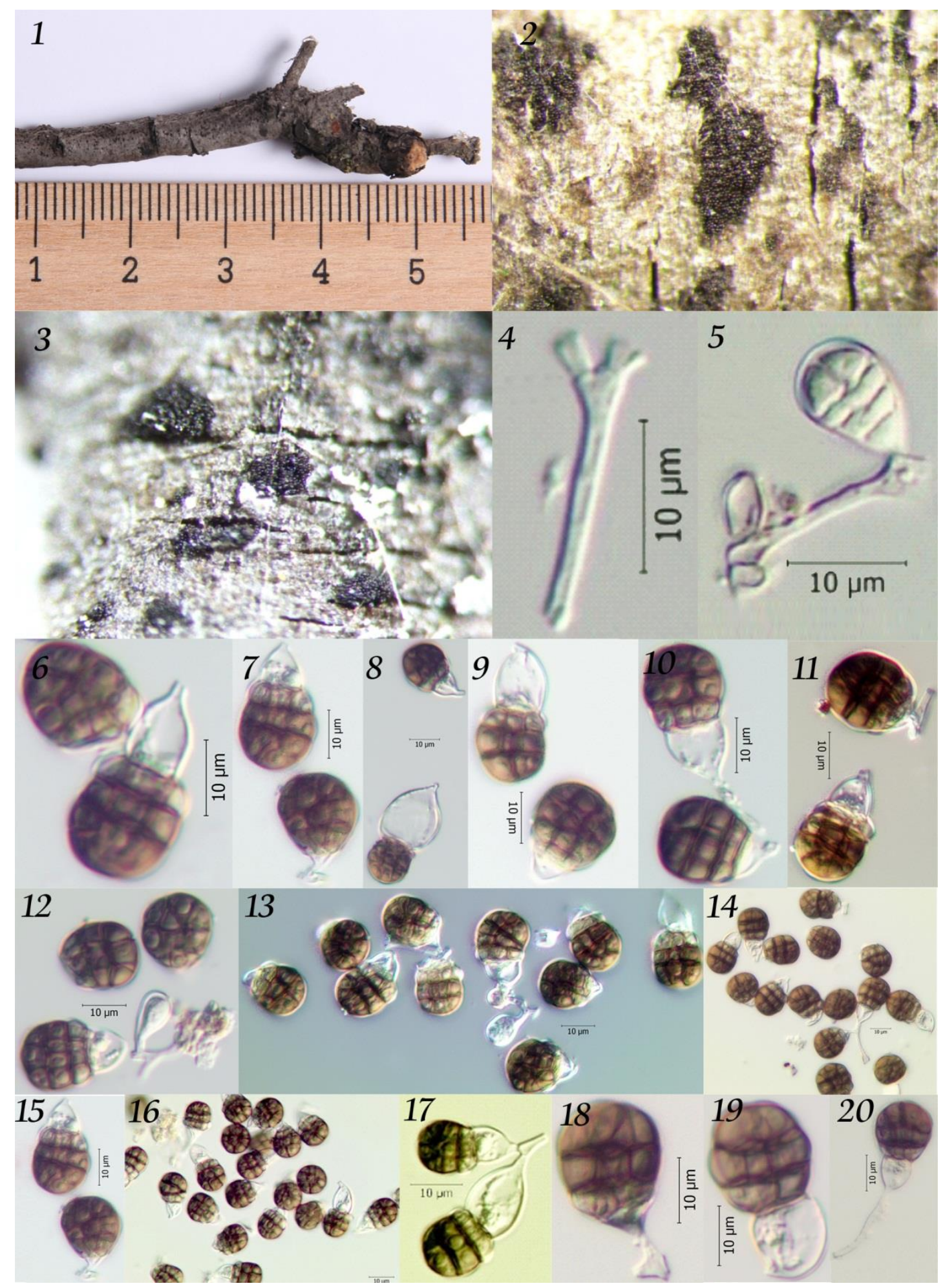

Figs 1-20 - Berkleasmium dudkae: 1 habit; 2-3 colonies; 4 branched conidiophore; 5 immature conidium and conidiophore; 6-20 variation in conidial size and shape. 


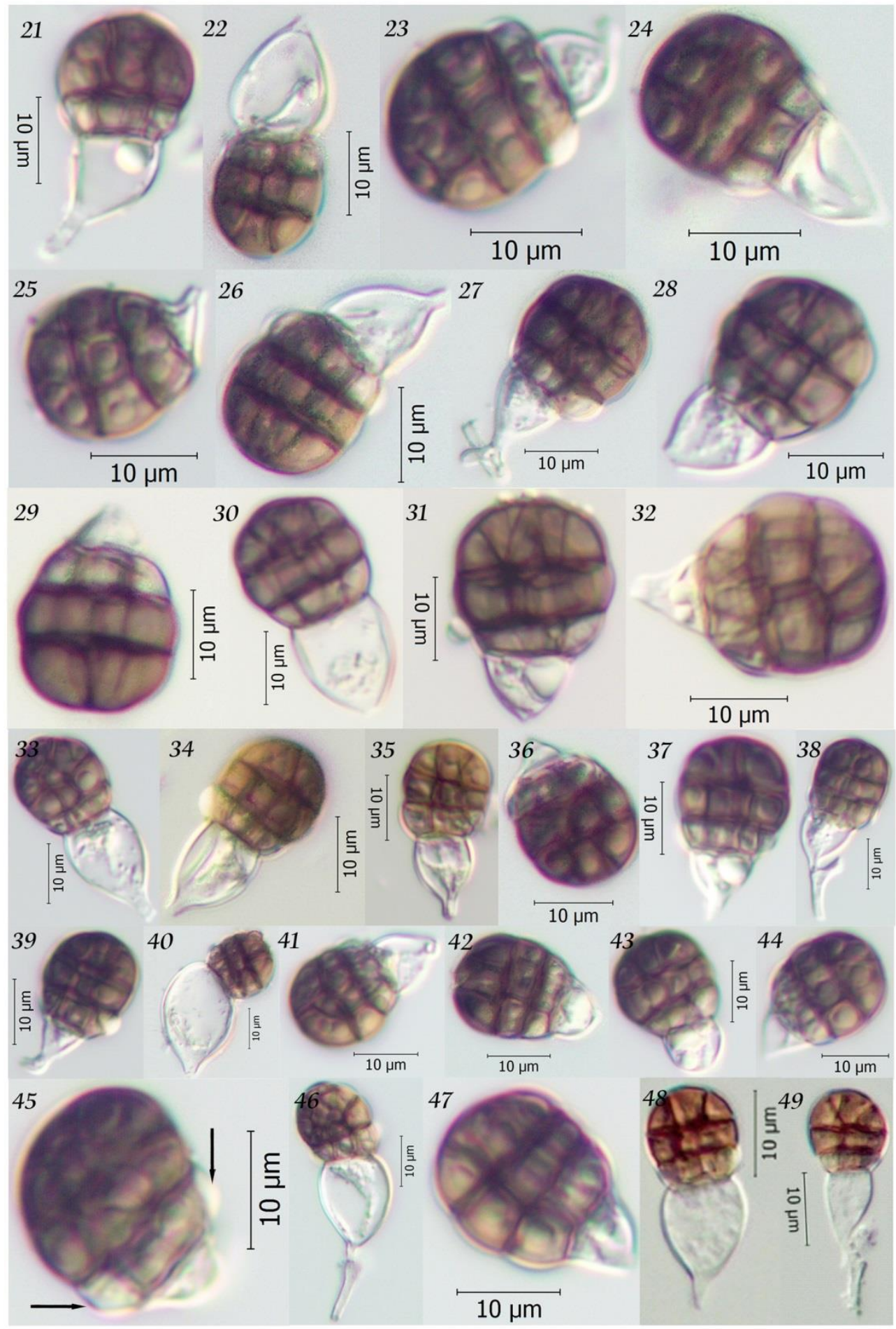

Figs 21-49 - Berkleasmium dudkae: 21-49 variation in conidial size and shape; 45 conidium with projections.

Material examined - RUSSIA, Ulyanovsk Province, Sergilei District, Bolshiye Kluchichsha, coniferous-deciduous forest, on bark of a dead twig of Rhamnus catharticus L.

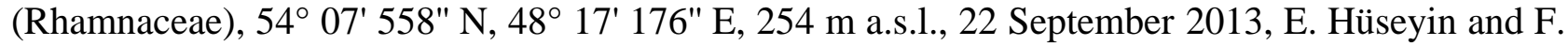
Selçuk (EH 904 - holotype).

Berkleasmium daphniphylli, B. juglandis, B. obovoides, B. pandani et B. typhae similis, sed conidiis ovalibus ad obovatae, (13-)14-17(-17.5) $\times 12.5-15 \mu \mathrm{m}, 2$ septum transversale et 1-2 septum longitudinale, 2 projecturis dentiformis. 
Conidiomata on natural substratum sporodochial, dispersed, superficial, scattered, punctiform, granular or slightly elongated, dark brown to black, shiny, 230-480 $\times 165-280 \mu \mathrm{m}$. Mycelium scanty, mostly immersed in the substratum, pale to medium brown, smooth or verruculose, branched hyphae. Conidiophores simple, macronematous, unbranched or occasionally branched, brownish, hyaline towards the apex, thin-walled, up to $25 \mu \mathrm{m}$ long, 1.8-2.3(-2.9) $\mu \mathrm{m}$ wide. Conidiogenous cells terminal, integrated, cylindrical, hyaline, 7.5-8 $\times 3-3.5 \mu \mathrm{m}$. Conidia solitary, acrogenous, oval to obovoid, smooth, regularly muriform, with 2 distinct transverse and 12 longitudinal and a few obscure oblique septa, slightly constricted at the septa, dark brown, (13)14-17(-17.5) × 12.5-15 $\mu \mathrm{m}$; always with a hyaline or subhyaline, guttulate, inflated, thin-walled, cup-shaped basal cell, 10-15(-17) $\times 10-12(-16) \mu \mathrm{m}$; on the lower row of cells of conidia are 2 well-marked hyaline odontoid projections, $4.3-6.1 \mu \mathrm{m}$ wide at the base, $1.75-2.57 \mu \mathrm{m}$ in height.

\section{Discussion}

The genus Berkleasmium contains several species where the conidia have an inflated basal cell, or when detached carry away part of the swollen conidiogenous cells. Such species are: $B$. corticola (P. Karst.) R.T. Moore (Moore 1959), B. inflatum Hol.-Jech. (Holubová-Jechová 1987), B. moriforme (Peck) R.T. Moore (Moore 1959), B. nigroapicale Bussaban, Lumyong, P. Lumyong, McKenzie \& K.D. Hyde (Bussaban et al. 2001), B. typhae Somrith. \& E.B.G. Jones (Somrithipol \& Jones 2003), B. taishanense G.Z. Zhao \& T.Y. Zhang 2004 (Zhao \& Zhang 2004), B. pandani McKenzie (McKenzie 2008), B. zhejiangense Wongs., H.K. Wang, K.D. Hyde \& F.C. Lin (Wongsawas et al. 2009), B. daphniphylli K. Zhang \& X.G. Zhang (Zhang et al. 2009), B. obovoides G.Z. Zhao (Qu et al. 2014) and B. juglandis (Mel'nik) G.Z. Zhao (Qu et al. 2014).

In conidial morphology, Berkleasmium dudkae most closely resembles $B$. daphniphylli, $B$. juglandis, B. obovoides, B. pandani and B. typhae. They all produce obovate and muriform conidia. However, the conidia of $B$. daphniphylli are 16.5-28 $\times 10-13 \mu \mathrm{m}$ with 4-5 (mostly 4) regular parallel transverse septa (Zhang et al. 2009). Those of B. juglandis are 22-30 $\times 16-22 \mu \mathrm{m}$ with usually 4(-5) transverse septa (Mel'nik 1988, 2000). The conidia of B. obovoides are 26-34 $\times 19$ $24 \mu \mathrm{m}$ with usually 3 transverse septa (Qu et al. 2014). B. pandani has swollen conidiogenous cells and conidia 27-34 × 18-22.5 $\mu \mathrm{m}$ (McKenzie 2008). The conidia of B. typhae are 23-28.5 $\times 15-$ $19.5 \mu \mathrm{m}$ with irregular transverse septa, and more common inflated conidiophores (Somrithipol \& Jones 2003).

According to Seifert et al. (2011), the genus Berkleasmium comprises 32 species on wood, palms and other litter in Africa, Asia, Australasia and North America. A further species, a new combination and a key to 34 species was provided by Whitton et al. (2012). There are presently 39 species in Berkleasmium, 35 of them are registered in Index Fungorum (2014), three new species were described from China and Monodictys juglandis Mel'nik (Mel'nik 1988) was transferred to Berkleasmium as B. juglandis (Mel'nik) Zhao (Qu et al. 2014).

Two species of Berkleasmium have been previosly reported in Russia. They are $B$. concinnum (Berk.) S. Hughes and B. juglandis (as Monodictys juglandis) (Mel'nik 2000).

\section{Acknowledgements}

We are deeply grateful to Dr. Roland Kirschner (National Central Univrersity, Taiwan) for his valuable comments and advice. The authors express thanks to Ahi Evran University and Ulyanovsk State University Project managing offices for financial support (Project no: 4001.13.003).

\section{References}

Bussaban B, Lumyong S, Lumyong P, McKenzie EHC, Hyde KD. 2001 - A synopsis of the genus Berkleasmium with two new species and new records of Canalisporium caribense from Zingiberaceae in Tailand. Fungal Diversity 8, 73-85. 
Holubová-Jechová V. 1987 - Studies on hyphomycetes from Cuba V. Six new species of dematiaceous Hyphomycetes from Havana Province. Česka Mykologie 41, 29-36.

McKenzie EHC. 2008 - Two new dictyosporous hyphomycetes on Pandanaceae. Mycotaxon 104, 23-28.

Mel'nik VA. 1988 - New species hyphomycetes and coelomycetes from collections in the Altai Mountains and Soviet Far East. Mikologiya i Fitopatologiya 22, 492-500.

Mel'nik VA. 2000 - Definitorium Fungorum Rossiae. Classis Hyphomycetes. Fasc.1. Fam. Dematiaceae. Nauka, Petropoli. [in Russian].

Moore RT. 1959 - The genus Berkleasmium. Mycologia 51, 734-739.

Qu Ch, Yin G, Zhao G, Cui B, Liu X. 2014 - Three new species of Berkleasmium (Hyphomycetes) from China. Nova Hedwigia 98, 151-161.

Seifert K, Morgan-Jones G, Gams W, Kendrick B. 2011 - The genera of Hyphomycetes. CBS Biodiversity Series 9, 1-997.

Somrithipol S, Jones EBG. 2003 - Berkleasmium typhae sp. nov., a new hyphomycete on narrowleaved cattail (Typha angustifolia) from Thailand. Fungal Diversity 12, 169-172.

Whitton SR, McKenzie EHC, Hyde KD. 2012 - Anamorphic fungi associated with Pandanaceae. In: Whitton SR, McKenzie EHC \& Hyde KD, Fungi associated with Pandanaceae. Fungal Diversity Research Series (Hong Kong) 21, 125-353.

Wongsawas M, Wang HK, Hyde KD, Lin FC. 2009 - Two new hyphomycetes from submerged wood collected in China. Sydowia 61, 345-351.

Zhang K, Ma J, Ma LG, Zhang XG. 2009 - A new species of Berkleasmium from Chongqing, China. Mycotaxon 108, 5-7.

Zhao GZ, Zhang XG. 2004 - Notes on dictyosporic fungi from China IV. The genus Berkleasmium. Mycotaxon 89, 241-244. 